\title{
Feeding Behaviour of Diabrotica virgifera virgifera Adults on Corn Crops
}

\author{
Ioana GROZEA ${ }^{1 *}$, Ramona STEF ${ }^{1}$, Ana Maria VIRTEIU ${ }^{1}$, Levente MOLNAR ${ }^{1}$, Alin CARABET $^{1}$, Carmen \\ PUIA $^{2}$, Ionela DOBRIN ${ }^{3}$ \\ ${ }^{1}$ Department of Biology and Plant Protection, Banat's University of Agricultural Sciences and \\ Veterinary Medicine "King Michael I of Romania" Timisoara, Romania; \\ ${ }^{2}$ Department of Environment and Plant Protection, University of Agricultural Science and Medicine \\ Veterinary, Cluj Napoca; \\ ${ }^{3}$ Faculty of Agriculture, University of Agricultural Science and Medicine Veterinary, București, Romania \\ *)corresponding author, e-mail: ioana_entomol@yahoo.com
}

BulletinUASVM Horticulture 72(2) / 2015

Print ISSN 1843-5254, Electronic ISSN 1843-5394

DOI:10.15835/buasvmcn-hort:11393

\begin{abstract}
Diabrotica virgifera virgifera Le Conte (Coleoptera:Chrysomelidae), is an invasive pest in corn crops, known as western corn rootworm. For this, serious measures were taken to limit the spread; however it continued to expand and adapt to new areas. One of the causes responsible for invading is capacity of adapting to abiotic and biotic factors in the new habitat. Having in mind the orientation for adults and especially for flowering plants pollen we wanted to see if behavior of Diabrotica from a corn crop, at a time, is influenced by the presence and diversity of weeds. Observations were made during year of 2014, in July and August, in a place in western Romania. It was chased feeding behavior toward both corn plant and weed and the other hand, the level of population was observed. In our study we found that adults are attracted to flowers weeds; they found on much greater numbers in corn plot with weed abundant comparative the plot without weeds. Females predominated in corn crop with different weed species present.
\end{abstract}

Keywords: corn, Diabrotica virgifera, field, invasive insect, weeds.

\section{Introduction}

Since the first discovery of Diabrotica virgifera virgifera Le Conte (Western Corn Rootworm) in 1992, near Belgrade, the insect spread considerably and adapted to new host plants . Most information from scientific literature revealed that adults prefer corn plants, but it can feed on different plants cultivated or spontaneous when alternative sources of pollen are available (Moeser and Vidal, 2005; Sivcev et al., 2012). Adults are attracted to plants spontaneous in blossom after disappearance of silk and corn pollen especially to species of the genus Amaranthus, Chenopodium and Ambrosia (Moeser and Vidal, 2005; Tallamy et al., 2005).

\section{Aims and objectives}

The main purpose of this paper was to see if the weed degree influences the insect population level. As objectives we mentioned first, the preference for weed through pollens found in the body beetles and second the level of adults in both, weed and no-weed corn field.

\section{Materials and methods}

Research has been organized in 2 experimental corn plots (I- abundant weeds; II-no weeds) situated at a distance of $1000 \mathrm{~m}$, in a place in western Romania (Sag locality, Timis County). Observations were made in the period of maximum activity adult feeding. From each plot were collected every 25 beetles; pollen analysis was performed by dissecting them. For anesthesia was used acetate to be kept damp. To quantify females and males were used pheromone traps (Csalomon). 
Tab. 1. The adults of Diabrotica virgifera virgifera Le Conte preference status for weed species

\begin{tabular}{ccccc}
\hline \multirow{2}{*}{ Species } & \multicolumn{2}{c}{ Beetles observed on plants } & \multicolumn{2}{c}{ Pollen found in beetles body } \\
\cline { 2 - 5 } & I- abundant weeds & II-no weeds & I- abundant weeds & II-no weeds \\
\hline Zea mays & $* * *$ & $* * *$ & $* * *$ & $* * *$ \\
\hline Sorghum halepense & $* *$ & $*$ & $* *$ & $*$ \\
\hline Chenopodium album & $* *$ & $*$ & $* *$ & $*$ \\
\hline Datura stramonium & $* *$ & $*$ & $*$ & $*$ \\
\hline Cirsium arvense & $* *$ & $*$ & $*$ & $*$ \\
\hline Setaria sp. & $* *$ & $*$ & $*$ & $*$ \\
\hline Echinochloa crus- galli & $* *$ & $*$ & $*$ & $*$ \\
\hline Amaranthus sp. & $*$ & $*$ & $*$ & $*$ \\
\hline Polygonum convolvulus & $*$ & $*$ & $*$ & $*$ \\
\hline Ambrosia artemisifolia & $* *$ & $*$ & $*$ & $*$ \\
\hline Solanum nigrum & $*$ & $*$ & $*$ & $*$ \\
\hline Xanthium strumarium & $* *$ & $*$ & $*$ & $*$ \\
\hline Abutilon theophrasti & $*$ & $*$ & $* *$ & $*$ \\
\hline Convovulus arvensis & $*$ & $*$ & $*$ & $*$ \\
\hline Sonchus arvensis & $* *$ & $*$ & $*$ & $*$ \\
\hline Galinsoga parviflora & $* *$ & $*$ beetles have observed on plant/pollen present in body \\
*f beetles have no observed on plant/pollen missing in body ofbeetles; beetles have present in all maize plots & $* *$ & $*$ & $*$ \\
\hline
\end{tabular}

Tab. 2. Comparative data regarding the number of adults in both variants

\begin{tabular}{|c|c|c|c|c|c|}
\hline \multirow{2}{*}{ Variant } & \multicolumn{2}{|c|}{ Beetles observed on plants } & \multicolumn{2}{|c|}{ Number of adults/trap } & \multirow{2}{*}{$\begin{array}{c}\text { Average/ } \\
\text { variant }\end{array}$} \\
\hline & $q$ & $\pi$ & 우 & $\pi$ & \\
\hline I- abundant weeds & 456 & 379 & 167 & 288 & 322.5 \\
\hline II-no weeds & 272 & 200 & 134 & 207 & 203.25 \\
\hline Average/sex ratio/type of quantification & 364 & 298.5 & 150.5 & 247.5 & \\
\hline
\end{tabular}

\section{Results and Discussion}

In our study we found that adults are attracted to flowers weeds; they found on much greater numbers in corn plot with weed abundant comparative the plot without weeds. Females predominated in maize crop with different weed species present (Table 2). Of those 15 species of weeds, 10 were visited by beetles (Table 1 ). After examining pollen (in terms of quantity and quality) from adults collected from the plot full of weed, we revealed that 55\% from analyzed pollen belonged to wild plants (weeds). In corn plot free of weeds was found weed pollen but in small amount (5\%); is assumed that it was collected by beetles from the weeds the surroundings plot.

\section{Conclusion}

Population level of Diabrotica virgifera virgifera adults increases considerably in corn with abundant weeds so it requires a permanently maintenance of maize crops free of weeds.

\section{REFERENCES}

1. Moeser J, Vidal S (2004). Do alternative host plants enhance the invasion of the maize pest Diabrotica virgifera virgifera (Coleoptera: Chrysomelidae, Galerucinae) in Europe? Environmental Entomology 33(5): 1169-1177.

2. Moeser J, Vidal S (2005). Nutritional resources used by the invasive maize pest Diabrotica virgifera virgifera in its new Southeast-European distribution range. Entomologia Experimentalis et Applicata 114: 55 - 63.

3. Sivčev I, Kljajić P, Kostić M, Sivčev L Slađan S (2012). Management of Western Corn Rootworm (Diabrotica virgifera virgifera. Pesticides and Phytomedicine 27(3): 189-201.

4. Tallamy DW, Hibbard BE, Clark TL, Gillespie JJ (2005). Western corn rootworm, Cucurbits and Cucurbitacins. In: "Western Corn Rootworm, Ecology and Management" (S. Vidal, U. Kuhlmann, C.R. Edwards, eds.) CABI Publishing, Wallingford. 310. 